\title{
Evaluation of Antioxidant Activity and Cytotoxicity in Mixture Extract of Artemisia asiatica Nakai and Moringa oleifera Lam
}

\author{
Yoon-Ji Lee $^{1, *}$, Jang-Oh Kim ${ }^{1, *}$, Chan-Hee Jeon ${ }^{1, *}$, Ji-Eun Lee ${ }^{1, *}$, \\ Ji-Hye Shin ${ }^{1, *}$ and Byung-In Min ${ }^{2, \dagger, * *}$ \\ ${ }^{I}$ Department of Emergency and Disaster Management, Inje University, Gimhae-si 50834, Korea \\ ${ }^{2}$ Department of Nuclear Applied Engineering, Inje University, Gimhae-si 50834, Korea
}

\begin{abstract}
The purpose of this study was performed to evaluate antioxidant activity of the Artemisia asiatica Nakai and Moringa oleifera Lam mixture extract. Mixture extracts were manufactured by concentration and compared with a single extract (only the Artemisia asiatica Nakai mixture and only the Moringa oleifera Lam mixture). The experiments conducted Total polyphenol measurements, Total flavonoid measurements, DPPH radical scavenging activty, ABTS radical scavenging activty and LDH assay. The LDH assay assessment shows that all extracts are cells compared to controls. The toxicity was weak. Finally, The antioxidant capacity was rated higher than mixture extract of a single extract. Also, the optimized mixture was determined AM5 (Artemisia asiatica Nakai mixture: Moringa oleifera Lam mixture $=3: 1$ ). For extracts of AM5, Total phenol and flavonoid contents were $271.769 \pm 18.087 \mathrm{mg} / \mathrm{g}$ and $45.384 \pm 5.026 \mathrm{mg} / \mathrm{g}$. and DPPH and ABTS scavenging activity were $70.8 \pm 6.496 \%$ and $77.1 \pm 9.634 \%$. Therefore, it is expected that the value of the extract will increase as it increases its antioxidant activity if it is manufactured according to the appropriate ratio.
\end{abstract}

Key Words: Artemisia asiatica Nakai, Moringa oleifera Lam, Antioxidant activity, Free radical

\section{서 론}

21세기 산업 기술이 발달함에 따라 큰 변화를 초래한 것 중 하나가 '식습관 변화'이다. 현대사회에서 서구식 식 습관을 수용함으로써 외식문화 확대 및 각종 가공식품, 즉석식품(fast food), 고칼로리 식품을 과잉 섭취하게 되었 기 때문이다(Kim et al., 2009). 따라서 이러한 식습관 변화 로 인해 최근에는 비만, 성인병, 고혈압, 당뇨병을 기반으 로 암 발병률이 높아졌다. 이 질병들은 치료보다는 예방 이 우선이기에 식습관을 개선할 필요가 있다. 따라서 현 재 항암, 항당뇨, 염증 및 노화 예방에 효능이 있는 항산
화 식품들의 연구가 필요한 실정이다.

그 중 개발된 뷰틸하이드록시아니솔(Butylated Hydroxy Anisole, BHA), 디부틸하이드록시톨루엔(Di dibutyl hydroxy toluene, BHT) 등의 합성 항산화제는 일정량의 복용 이상 시 독성을 일으킬 문제가 있다고 보고되었다(Branen, 1975). 이에 반해 천연 항산화 물질은 장기간 복용 시 부작용이 적으며 항산화 효과가 높아 여러 가지 생리 활성을 작용 할 수 있다고 알려져 있다. 이들의 효능이 알려짐으로써 천연 항산화 물질의 연구가 각광받고 있다.

본 연구에서 천연 물질 재료로 사용한 애엽과 모링가 중 애엽(Artemisia asiatica Nakai)은 황해쑥(Artemisia argyi Lev. et Vant.), 쑥(A. Princeps Pamp. var. orientlis Hara)의 잎을

Received: September 10, 2020 / Revised: December 18, 2020 / Accepted: December 18, 2020

* Graduate student, ${ }^{* *}$ Professor.

${ }^{\dagger}$ Corresponding author: Byung-In Min. Department of Nuclear Applied Engineering, Inje University, 197, Inje-ro, Gimhae-si, Gyeongsangnam-do 50834, Korea.

Tel: +82-55-320-3910, Fax:+82-55-337-1303, e-mail: rimbi@inje.ac.kr

(C) The Korean Society for Biomedical Laboratory Sciences. All rights reserved.

(c) This is an Open Access article distributed under the terms of the Creative Commons Attribution Non-Commercial License (http:/creativecommons.org/licenses/by-nc/3.0/) which permits unrestricted non-commercial use, distribution, and reproduction in any medium, provided the original work is properly cited. 
말린 약재로서 항균, 항암 및 항산화 작용(Jeong et al., 2007), 항균 작용(Sung, 2009), 혈압 강하 작용(Kim et al., 1981) 등 에 효능이 있다. 애엽에는 Eupatilin과 Jaceosidin의 flavonoid 성분(Ryu et al., 2004)을 함유하고 있다. 특히 Jaceosidin은 세포 자멸 유도와 선택적으로 암세포 증식을 억제하는 효 과(Han et al., 2018)가 있다고 보고되었다. 모링가(Moringa oleifera Lam)는 낙엽 활엽교목에 속하며 모링가의 잎을 더불어, 꽃, 봉우리, 씨앗 및 열매 등 약물로서 섭취(Anwar and Bhanger, 2003)를 하고 있다. 또한 모링가는 항당뇨, 암 세포 사멸, 항종양 및 간 손상 방지에 효능이 있다(Anwar et al., 2007)고 알려져 있다. 그 중 모링가 잎은 다량의 polyphenol 및 flavonoid 성분이 들어있어 항산화 효능에 뛰어나다고 알려져 있다(Choi and Kim, 2015). 현재까지 애엽 및 모링가 추출물에 대한 효능이 알려지면서 항산화 식품으로 응용하고 있다.

이처럼 천연 물질마다 polyphenol 및 flavonoid를 구 성하는 성분은 다르다. 위에 나타난 바와 같이 애엽은 Jaceosidin을 함유하고 있으나 모링가는 함유하고 있지 않 다. 그러므로 애엽과 모링가의 양을 달리하여 혼합한 후 열수추출을 하면 추출되는 polyphenol 및 flavonoid의 양은 다를 것으로 판단된다. 즉 polyphenol 및 flavonoid를 구성 하는 성분이 다르기 때문에 항산화 능력에 대한 매커니즘 또한 다르게 작용할 것으로 기대된다.

따라서 본 연구는 애엽-모링가 혼합 추출물을 일정 비 율에 따라 제조하여 단일 추출물과 혼합 추출물의 항산 화 효과를 비롯하여 생리 활성 효능을 평가하고 가장 효 과적인 혼합 비율을 찾고자 한다.

\section{재료 및 방법}

\section{실험재료}

실험에 사용된 애엽(Artemisia asiatica Nakai)은 애엽 $100 \%$ 분말로 (주)열린약초(Seoul, Korea)에서 구매하였으 며 모링가 잎(Moringa oleifera Lam) 분말은 부산시 국제시 장에서 구입하여 사용하였다.

\section{추출물의 제조}

애엽-모링가분말의 단일 및 혼합 추출물은 Table 1 과 같이 혼합하여 사용하였다. Choi의 혼합 추출물 항산화 평 가 실험방법을 응용하여 애엽분말과 모링가분말의 혼합 추출물은 애엽:모링가 비율을 100:0부터 0:100까지 $25 \%$ 씩 증가시키면서 혼합하여 실험에 사용하였다(Choi et al.,
Table 1. Sample name and Ratio of Artemisia asiatica Nakaiand and Moringa oleifera Lam mixture

\begin{tabular}{lc}
\hline $\begin{array}{l}\text { Sample } \\
\text { name }\end{array}$ & $\begin{array}{c}\text { Mixture ratio (\%) } \\
\text { (Artemisia asiatica Nakai: Moringa oleifera Lam) }\end{array}$ \\
\hline AW & $100: 0$ \\
MW & $0: 100$ \\
AM1 & $50: 50 \quad(1: 1)$ \\
AM2 & $33.3: 66.7(1: 2)$ \\
AM3 & $66.7: 33.3(2: 1)$ \\
AM4 & $25: 75 \quad(1: 3)$ \\
AM5 & $75: 25 \quad(3: 1)$ \\
\hline
\end{tabular}

AW: water extract of Artemisia asiatica Nakai, MW: water extract of Moringa oleifera Lam, AM1, 2, 3, 4, 5: Each hot water extract by mixture ratio

2012). 애엽, 모링가분말 시료에 증류수를 $1: 10(\mathrm{w} / \mathrm{v})$ 으로 첨가하여 $100^{\circ} \mathrm{C}$ 에서 3 시간 동안 환류냉각을 2회 반복하여 추출하였다. 애엽-모링가 단일 및 혼합 추출물은 Filter paper (Toyo roshi kaisha, Ltd, Japan)로 여과한 후 감압 농 축한 다음 Rotary Evaporator (R-100, BUCHI)를 이용하여 건조한 후 사용하였다.

\section{Total polyphenol 측정}

애엽-모링가 혼합 추출물의 총 polyphenol 함량은 FolinDenis 방법 등을 응용하여 분석하였다(Hong et al., 2011). 이 분석법은 Folin-ciacalteu reagent가 시료의 polyphenol 성 화합물에 의해 몰리브덴을 청색으로 변하게 한다. 이 변화 량은 추출물의 polyphenol 성 화합물에 의해 환원량을 나 타낸다. 각 시료 추출물 $200 \mu \mathrm{L}$ 에 $2 \% \mathrm{Na}_{2} \mathrm{CO}_{3}$ 용액 $4 \mathrm{~mL}$ 를 가하여 3 분간 방치한 뒤 $50 \%$ Folin-Ciocalteu reagent $200 \mu \mathrm{L}$ 를 첨가하여 실온에서 30 분간 반응시켰다. 반응시 킨 시료는 UV-Vis Spectrophotometer (Mega-V600, SINCO) 을 사용하여 $700 \mathrm{~nm}$ 에서 측정하였다. 표준 물질은 gallic acid로 하여 일정 농도별 $(0.001,0.01,0.1,1 \mathrm{mg} / \mathrm{g})$ 로 조제 한 후 시료와 동일한 방법을 거친 뒤 검량선을 작성하였 다. 표준곡선 식을 구하여 시료용액 흡광도를 식에 대입 하여 총 페놀 함량을 구하였다. 애엽-모링가 단일 및 혼 합 추출물에 함유된 총 페놀 함량 $(\mathrm{GAE} \mathrm{mg} / \mathrm{g})$ 은 시료 $1 \mathrm{~g}$ 당 $\mathrm{mg}$ garlic acid 기준으로 나타냈다.

\section{Total flavonoid 측정}

애엽-모링가 혼합 추출물의 Total flavonoid 함량은 Jia 방법 등을 응용하여 분석하였다(Jia et al., 1999). 각 시료 
추출물 $50 \mu \mathrm{L}$ 에 증류수 $30 \mu \mathrm{L}$ 를 첨가하여 실온 $25^{\circ} \mathrm{C}$ 에서 5 분간 반응시켰다. 그 후 $5 \% \mathrm{NaNO}_{2}$ 용액 $15 \mu \mathrm{L}$ 를 첨가하 여 5 분 후 $10 \% \mathrm{AlCl}_{3}$ 용액 $30 \mu \mathrm{L}$ 를 섞어 6 분간 상온에서 방치한 후 $1 \mathrm{~N} \mathrm{NaOH}$ 용액 $100 \mu \mathrm{L}$ 를 첨가하였다. 반응액 은 ELISA reader (biotek, USA) $520 \mathrm{~nm}$ 에서 흡광도를 측 정하였다. 표준 물질은 Hesperidin으로 하여 일정 농도별 $(100,200,300,400,500 \mu \mathrm{g} / \mathrm{mL})$ 로 조제한 후 시료와 동일한 방법을 거친 뒤 검량선을 작성하였다. 표준곡선 식을 구 하여 시료용액 흡광도를 식에 대입하여 총 flavonoid 함량 을 구하였다. 애엽-모링가 단일 및 혼합 추출물에 함유된 총 flavonoid 함량 $(\mathrm{HE} \mathrm{mg/g})$ 은 시료 $1 \mathrm{~g}$ 당 $\mathrm{mg}$ hesperidin 기준으로 나타냈다.

\section{항산화 능력 평가}

DPPH radical 소거능: 애엽-모링가 혼합추출물의 항산 화 능력은 Soumaya, Kim 등의 방법을 응용하여 분석하였 다(Soumaya et al., 2005; Kim et al., 2011). 이 분석법은 DPPH (2,2-Dipheny-1-picrylhydrazyl) 용액이 항산화 물질과 반응하 면 전자를 내어주고 radical이 소멸되어 노란색으로 변하 는 원리이다(Hiroshi and Mitsuaki, 1999). 이 변화량이 추출 물이 가지고 있는 활성산소를 제거하는 능력을 나타낸다 (Jeong et al., 2004). 각 추출물과 $0.2 \mathrm{mM} \mathrm{DPPH}$ 용액과 1:1 비율로 반응시킨 다음 $520 \mathrm{~nm}$ 에서 흡광도를 측정한다. 다음 계산식을 통해 DPPH radical 소거능을 계산하였다.

$$
\text { DPPH Scavenging activity }(\%)=1-\frac{\text { Sample O. D }}{\text { Control O. D }} \times 100
$$

ABTS radical 소거능: 애엽-모링가 혼합 추출물의 항산 화 능력은 Lee 방법에 따라 응용하여 분석하였다(Lee and Moon, 2019). 이 분석법은 ABTS radical이 과황산칼륨 (Potassium persulfate)과의 반응에서 생성된 항산화 물질에 의해 ABTS free radical이 제거되어 radical이 청록색으로 변한다. 이 변화량이 항산화제에 의한 환원력을 나타낸 다. 애엽-모링가 농도별 혼합 추출물에 $2.45 \mathrm{mM}$ 과황화 칼륨과 $7 \mathrm{nM} \mathrm{ABTS}$ 용액을 혼합하여 암소에서 24시간 방치하여 $\mathrm{ABTS}^{+}$을 생성하였다. $734 \mathrm{~nm}$ 에서 측정하여 흡광도 값이 $0.70 \pm 0.02$ 가 되게 Ethanol로 희석하여 조정 하였다. 추출물 및 양성대조군 $0.1 \mathrm{~mL}$ 와 ABTS 용액 $0.9 \mathrm{~mL}$ 를 혼합하여 6분간 반응시킨 후 UV-Vis Spectrophotometer (Mega-V600, SINCO) $734 \mathrm{~nm}$ 에서 흡광도 측정 하였다. 다음 계산식을 통해 ABTS radical 소거능을 계산 하였다.
$\mathrm{ABTS}^{+}$Scavenging activity $(\%)=1-\frac{\text { Sample O. D }}{\text { Control O. D }} \times 100$

\section{젖산탈수소효소(Lactacte dehydrogenase, LDH) 평가}

세포독성평가는 LDH assay를 실시하였다. 젖산탈수소효 소는 안정한 세포에서는 대부분 세포막을 통과하지 못하 기 때문에 세포막 밖으로 방출되지 못한다. 하지만 손상 된 세포에서 $\mathrm{LDH}$ 는 세포막 밖으로 방출하게 된다(Fotakis and Timbrell, 2006). 여기서 배지 내 LDH 양을 측정하여 세포독성(Cytotocity)을 알아보는 실험이다. 세포는 배아 신장 세포 HEK 293T 세포를 사용하였으며 실험은 LDH analysis kit를 사용하여 제공된 프로토콜을 따라 시행하였 다. 흡광도는 ELISA reader (biotek, USA) $490 \mathrm{~nm}$ 에서 측정 하였다.

\section{통계분석}

모든 실험은 3 회 반복 수행하여 mean $\pm \mathrm{SD}$ 로 나타내었 다. 각 추출물 간의 유의성 여부를 판단하기 위해 통계분 석은 SPSS (IBM SPSS statistics ver. 26)를 이용하여 일원배 치분산분석(ANOVA)과 사후분석(Duncan's multiple range test)을 실시하였다.

\section{결과 및 고찰}

\section{Total polyphenol}

polyphenol이란 분자 내 다수의 페놀(phenol) 작용기를 가지는 고분자이다. polyphenol은 활성산소(reactive oxygen species, ROS)와의 반응을 통해 활성산소를 안정 상태로 변화시켜 항산화제로 작용하여 식·약품으로 널리 응용되 고 있다(Brian and Kaudas, 2001). 따라서 polyphenol 함량이 높을수록 항산화 효과가 클 것으로 사료된다. 페놀 함량 은 Table 2 와 같다. 총 애엽-모링가 단일 추출물 및 혼합 추출물의 페놀 함량을 등량값으로 나타낼 때 각각의 애엽 및 모링가 단일 추출물은 $189 \mathrm{mg} / \mathrm{g}$ 및 $160 \mathrm{mg} / \mathrm{g}$ 이며 애엽 -모링가 비율별 혼합 추출물은 219 272 mg/g으로 나타났 다. 단일 추출물과 혼합 추출물의 함량을 보면 혼합 추출 물의 페놀 함량이 단일 추출물보다 더 높은 경향을 보였 다. 또한 애엽-모링가 혼합 추출물의 페놀 함량을 비교하 였을 때 AM 5>AM 3>AM 1>AM 2>AM 4 순으로 $160 \mathrm{mg} / \mathrm{g}$ $\mathrm{AM} 5$ 가 페놀 함량이 가장 높게 나타났다. 이는 애엽과 모 링가의 polyphenol을 구성하고 있는 성분이 다르기 때문 에 추출된 양이 다른 것으로 판단된다. $\mathrm{Kim}$ 등의 연구에 
Table 2. Total phenol and flavonoid contents of the water extracts from each hot water extract by mixture ratio

\begin{tabular}{lcc}
\hline \hline $\begin{array}{l}\text { Sample } \\
\text { name }\end{array}$ & $\begin{array}{c}\text { Total phenol } \\
\text { contents } \\
(\mathrm{mg} \mathrm{GAE} / \mathrm{g})^{1)}\end{array}$ & $\begin{array}{c}\text { Total flavonoid } \\
\text { contents } \\
(\mathrm{mg} \mathrm{HE} / \mathrm{g})^{1)}\end{array}$ \\
\hline $\mathrm{AW}^{2)}$ & $189.308 \pm 5.909^{3) \mathrm{b})}$ & $34.099 \pm 2.134^{\mathrm{a})}$ \\
$\mathrm{MW}^{2)}$ & $160.186 \pm 17.941^{\mathrm{a})}$ & $31.665 \pm 1.756^{\mathrm{a})}$ \\
$\mathrm{AM}^{2)}$ & $238.417 \pm 15.228^{\mathrm{cd})}$ & $40.737 \pm 3.999^{\mathrm{ab})}$ \\
$\mathrm{AM}^{2)}$ & $233.482 \pm 14.370^{\mathrm{c})}$ & $37.861 \pm 4.519^{\mathrm{ab})}$ \\
$\mathrm{AM}^{2)}$ & $259.661 \pm 10.306^{\mathrm{de})}$ & $41.401 \pm 3.407^{\mathrm{bc}}$ \\
$\mathrm{AM}^{2)}$ & $219.656 \pm 13.143^{\mathrm{c})}$ & $36.091 \pm 2.028^{\mathrm{bc})}$ \\
$\mathrm{AM}^{2)}$ & $271.769 \pm 18.078^{\mathrm{e})}$ & $45.384 \pm 5.026^{\mathrm{c})}$ \\
\hline$F$-value $(P)$ & $22.842^{* * *}(.000)$ & $5.505^{* *}(.004)$ \\
\hline
\end{tabular}

1) GAE: Gallic acid equivalents, HE: Hesperidin equivalents

2) Abbreviations: See Table 1 .

3) Results are represented as mean $\pm \mathrm{SD}$

4) $* P<0.05, * * P<0.01, * * * P<0.001$

의하면 삼백초 $194.60 \mathrm{mg} / \mathrm{g}$, 익모초 $191.62 \mathrm{mg} / \mathrm{g}$ polyphenol 함량을 측정하였다. 이 결과 자생식물에 비하여 애엽-모 링가 단일 및 혼합 추출물의 polyphenol 함량이 높다고 평가할 수 있다(Kim et al., 2012).

\section{Total flavonoid}

flavonoid란 벤젠(C6H6) 고리 2개와 3 개의 탄소(C3)가 연결된 구조를 갖는 화합물로서 식물의 열매, 꽃, 봉오리, 줄기 및 열매 등에 많이 함유하고 있다(Vijaya et al., 1995). 또한 활성산소를 소거하는 역할을 함으로써 항산화, 항염 증, 및 항암 효과가 있다. 따라서 flavonoid 함량이 높을 수록 높은 항산화력이 평가될 것이다. flavonoid 함량은 Table 2와 같다. 총 애엽-모링가 단일 추출물 및 혼합 추 출물의 flavonoid 함량을 등량값으로 나타낼 때 각각의 애 엽 및 모링가 단일 추출물은 $34 \mathrm{mg} / \mathrm{g}$ 및 $32 \mathrm{mg} / \mathrm{g}$ 이며 애 엽-모링가 비율별 혼합 추출물은 36 46 mg/g으로 나타났 다. 결과적으로 단일 추출물과 혼합 추출물의 flavonoid 함량을 비교하면 혼합 추출물의 함량이 높다. 또한 혼합 추출물의 flavonoid 함량을 비교하였을 때 $46 \mathrm{mg} / \mathrm{g}$ 으로 AM5가 flavonoid 함량이 가장 높게 나타났다. Kim 등의 연구에 따르면 식물 열수 추출물의 페놀 및 flavonoid 함 량을 비교하였을 때 대부분 페놀 함량이 flavonoid 함량이 더 높다고 보고되었다(Kim et al., 2004). 또한 페놀 함량과 항산화능은 비례적으로 나타나 페놀 및 flavonoid 함량의 차이가 클수록 항산화 능력이 높다고 평가하였다. 그러므 로 본 실험에서 사용된 애엽-모링가 추출물도 flavonoid

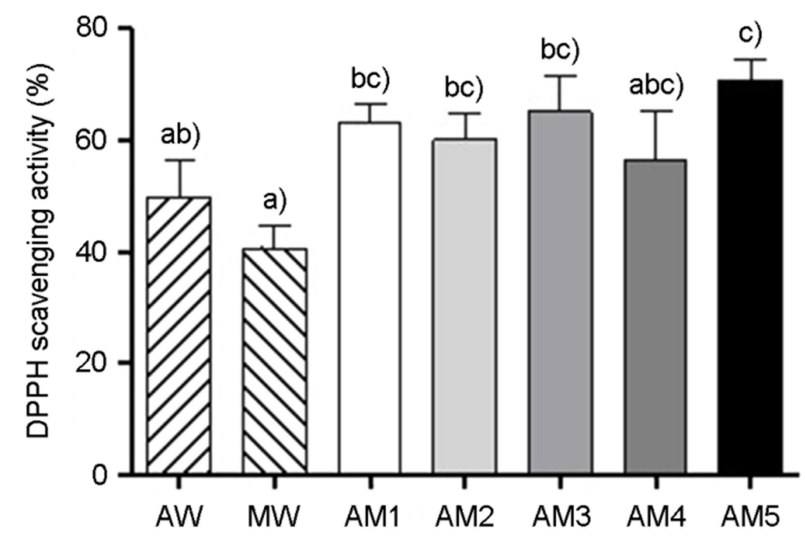

Fig. 1. The DPPH radical scavenging activity of hot water extract by single and mixture ratio a-c) the same column are significantly different at $* P<0.05$ (Duncan's multiple range test).

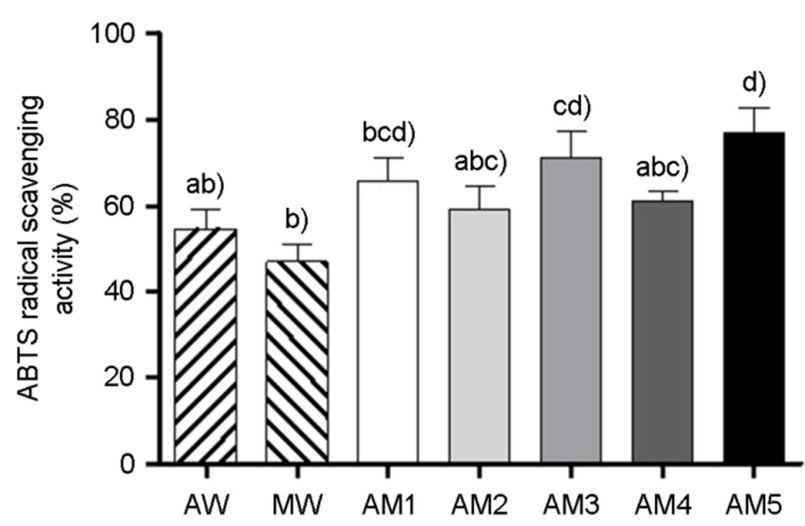

Fig. 2. The ABTS radical scavenging activity of hot water extract by single and mixture ratio a-d) in the same column are significantly different at $* * P<0.01$ (Duncan's multiple range test).

함량에 비하여 페놀 함량이 더 높게 측정되어 항산화 능 력이 우수할 것으로 평가된다.

\section{애엽-모링가 단일 및 혼합 추출물의 항산화 능력}

항산화 효과란 산화를 억제하는 효과를 말하며 항산화 력을 함유한 페놀 화합물 물질의 함량이 높을수록 활성 산소의 소거 활성이 증가한다(Shin, 1997). 따라서 총 페놀 및 flavonoid 함량의 변화가 활성산소 소거능에 영향을 미칠 것으로 사료된다. 애엽-모링가 단일 및 혼합 추출 물의 $\mathrm{DPPH}$ radical 소거능 결과는 Fig. 1과 같다. DPPH radical 소거능으로 애엽 및 모링가 단일 추출물은 $49.8 \%$ 및 $40.6 \%$ 이었으며 두 시료를 일정 비율로 혼합한 추출 물의 경우에 DPPH radical 56.2 70.8\%로 나타났다. 또한 


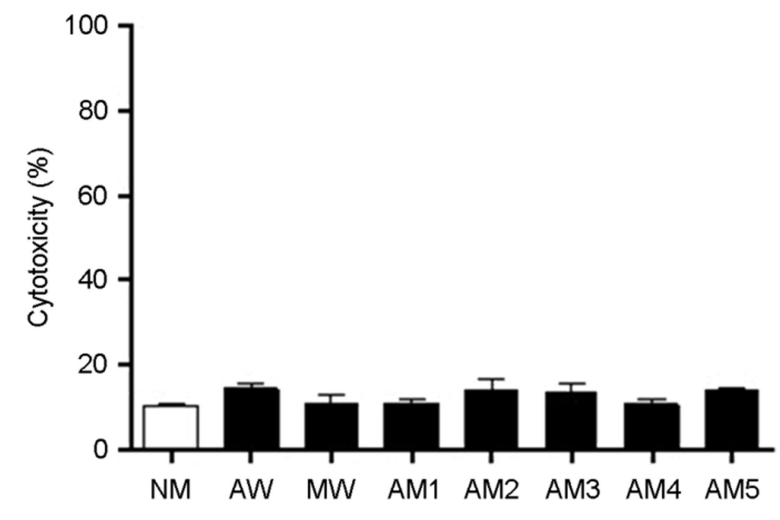

Fig. 3. Cytotoxicity of the extracts against HEK-293T cells in LDH assay.

양성 대조군인 Ascorbic acid의 소거능 $64.4 \%$ 와 비교하여 $\mathrm{AM} 3$ 및 AM5 추출물의 radical 소거 능력이 더 높게 나 타났다. Byun의 연구는 품종별 고추의 항산화 활성을 비 교한 결과 가장 우수한 DPPH radical 소거 활성을 가진 고추는 꽃고추 추출물로 $43.13 \%$ 를 나타냈다. 이 결과 애 엽-모링가 혼합 추출물은 꽃고추보다 더 뛰어난 항산화 능력을 가진 것을 확인할 수 있었다(Byun et al., 2016).

애엽-모링가 단일 및 혼합 추출물의 ABTS radical 소거 능 결과는 Fig. 2와 같다. ABTS radical 소거능으로 애엽 및 모링가 단일 추출물은 $54.7 \%$ 및 $47.2 \%$ 이었으며 두 시 료를 혼합한 추출물의 경우에 ABTS radical 59.3 77.1\% 로 나타났다. 또한 양성대조군 Ascorbic acid의 소거능 $58.6 \%$ 와 비교하여 소거능이 59.3 77.1\% 높게 측정되었다. 이 결과는 단일 추출물보다 혼합 추출물의 항산화 능력 이 더 높게 나타난 연구 결과와 비슷한 경향을 나타냈다 (Choi et al., 2012).

\section{LDH assay}

LDH assay를 이용하여 세포생존율을 평가하였다. HEK293 T cell에 애엽-모링가 단일 및 혼합 추출물을 처리 한 후 세포독성을 Fig. 3에 나타냈다. 대조군은 Medium (DMEM)을 사용하였다. 대조군과 비교하여 세포독성이 조금 증가하였지만 유의적인 차이가 나타나지 않았다. 이 는 애엽-모링가 단일 및 혼합 추출물의 세포독성 영향이 미미할 것으로 예상된다.

\section{ACKNOWLEDGEMENT}

This work was supported by the 2019 Inje University research grant.

\section{CONFLICT OF INTEREST}

There is no conflict of interest for all authors.

\section{REFERENCES}

Anwar F, Bhanger MI. Analytical characterization of Moringa oleifera seed oil grown in temperate region of Pakistan. Journal of Agricultural and Food Chemistry. Journal of Agricultural and Food Chemistry. 2003. 51: 6558-6563.

Anwar F, Latif S, Ashraf M, et al. Moringa oleifera: a food plant with multiple medicinal uses. Phytother Res. 2007. 21: 17-25.

Branen AL. Toxicology and biochemistry of butylated hydroxyanisol and butylated hydroxytoluene. Journal of the American Oil Chemists' Society. 1975. 5: 59-63.

Brian D, Kaudas S. The stimulation of phenolics and antioxidant activity in pea (Pisum sativum) elicited by genetically transformed anise root extract. Journal of Food Biochemistry. 2001. 25: 361-377.

Byun EB, Park WY, Ahn DH, et al. Comparison Study of Three Carieties of Red Peppers in Terms of Total Total Flavonoid contents, and Antioxidant Activities. Journal of the Korean Society of Food Science and Nutrition. 2016. 45: 765-770.

Choi EJ, Kim EK. Antioxidation, physicochemical, and sensory characteristics of sulgidduck fortified with water extracts from Moringa oleifera Leaf. Korean J Food Cook Sci. 2015. 31: 335-343.

Choi YH, Kim SE, Huh J, et al. Antibacterial and Antioxidative Activity of Roasted Coffee and Red Ginseng Mixture Extracts. The Korean Society of Food Science and Nutrition. 2012. 41: 320-326.

Fotakis G, Timbrell JA. In vitro cytotoxicity assays: Comparison of LDH, neutral red, MTT and protein assay in hepatoma cell lines following exposure to cadmium chloride. Toxicology Letters. 2006. 160: 171-177.

Han HY, Kim HJ, Jeong SH, Kim JY, et al. The Flavonoid Jaceosidin from Artemisia princeps Induces Apoptotic Cell Death and Inhibits the Akt Pathway in Oral Cancer Cells. Hindawi Evidence-Based Complementary and Alternative Medicine Volume. 2018.

Hiroshi KI, Mitsuaki T. 1,1-Diphenyl-2-Picrylhydrazyl Radical (DPPH) Scavenging Ability of Sake during Storage. Journal of Bioscience and Bioengineering. 1999. 87: 328-332.

Hong J, Kim HJ, Kim J. Factors Affecting Reactivity of Various Phenolic Compounds with the Folin-Ciocalteu Reagent. The 
Korean Society of Food Science and Nutrition. 2011. 40: 205 $-213$.

Jeong MA, Lee KW, Yoon DY, Lee HJ. Jaceosidin, a pharmacologically active flavone derived from Artemisia argyi, inhibits phorbol-ester-induced upregulation of COX-2 and MMP-9 by blocking phosphorylation of ERK-1 and -2 in cultured human mammary epithelial cells. Annals of the New York Academy of Sciences. 2007. 1095: 458-466.

Jeong SJ, Lee JH, Song HN, et al. Screening for Antioxidant Activity of Plant Medicinal Extracts. The Korean Society for Applide Biological Chemistry. 2004. 47: 135-140.

Jia Z, Tang M, Wu J. The determination of flavonoid contents in mulberry and their scavenging effects on superoxide radicals. Food Chemistry. 1999. 64: 555-559.

Kim EJ, Choi JY, Yu MR, et al. Total Polyphenols, Total Flavonoid Contents, and Antioxidant Activity of Korean Natural and Medicinal Plants. The Korean Society of Food Science and Technology. 2012. 44: 337-342

Kim EY, Baik IH, Kim, JH, et al. Screening of the Antioxidant Activity of Some Medicinal Plants. The Korean Society of Food Science and Technology. 2004. 36: 333-338.

Kim JD, Kim WK, Kim YT, Kim MJ. The difference for eating, activity, life pattern between obese and normal child who 5-6 grade in elementary school. Journal of Sport and Leisure Studies. 2009. 38: 855-865.

Kim JE, Kim AR, Kim MJ, et al. Antibacterial, Antioxidative and Antiaging Effects of Allium cepa Peel Extracts. Applied Chemistry for Engineering. 2011. 22: 178-184.

Kim YH, Shin HK, Kim KS. The drop is blood pressure in the Artemisia asiatica Nakai). The Korean Journal of Physiology and Pharmacology. 1981. 15: 91-96.

Lee HH, Moon YS. Assessment of the Important Factors Influencing Consistent and Accurate ABTS Assay. Journal of The Korean Society of Food Science and Nutrition. 2019. 48: 390 -393 .

Ryu SN, Kang SS, Kim JS, et al. Quantitative analysis of Eupatilin and Jaceosidin in Artemisia herba. The Korean Society of Crop Science. 2004. 49: 452-456.

Shin DH. Research Trends and Directions of Natural Antioxide. Korean Society of Food Science and Technology. 1997. 30: 14-21.

Soumaya K, Ribai BA, Inès B, et al. Investigation of extracts from (Tunisian) Cyperus rotundus as antimutagens and radical scavengers. Environmental Toxicology and Pharmacology. 2005. 20: 478-484.

Sung K. A study on the pharmacetical and chemical characteristics of natural artemisia extract. Journal of the Korean Applied Science and Technology. 2009. 26: 51-59.

Vijaya K, Ananthan S, Nalini R. Antibacterial effect of theaflavin, polyphenon 60 (Camellia sinensis) and Euphorbia hirta on Shigella spp. - a cell culture study. Journal of Ethnopharmacology. 1995. 49: 115-118.

https://doi.org/10.15616/BSL.2020.26.4.296

Cite this article as: Lee $\mathrm{YJ}$, Kim $\mathrm{JO}$, Jeon $\mathrm{CH}$, Lee JE, Shin JH, Min BI. Evaluation of Antioxidant Activity and Cytotoxicity in Mixture Extract of Artemisia asiatica Nakai and Moringa oleifera Lam. Biomedical Science Letters. 2020. 26: 296-301. 